\title{
Potential Application of Geographic Information System (GIS) in Reservoir Fisheries
}

\section{Semih Kale ${ }^{*}$ and Deniz Acarli²}

1Department of Fishing and Fish Processing Technology, Faculty of Marine Sciences and Technology, Çanakkale Onsekiz Mart University, Turkey

${ }^{2}$ Department of Fisheries Technology, Gökçeada School of Applied Sciences, Çanakkale Onsekiz Mart University, Turkey

*Corresponding author: Semih Kale, Department of Fishing and Fish Processing Technology, Faculty of Marine Sciences and Technology, Çanakkale Onsekiz Mart University, Çanakkale, Turkey, Tel: +902862180018/2304; Email: semihkale@comu.edu.tr

\section{Abstract}

Geographic Information Systems (GIS) is a computer based system for capturing, storing, checking, integrating, manipulating, analysing and displaying spatial data on the Earth. Reservoirs are man-made ecosystem established by impounding water of river for storing and supplying water, irrigation, generation of hydro-electric power, flood control, and fish production. Fisheries in reservoirs might be affected by productivity, prey/predator abundance, or physical features of water and habitat However, modelling of these relationships could be difficult due to the dynamic natures of aquatic ecosystems.GIS is an important tool for analysing these multidimensional spatial patterns and evaluating the impacts on reservoir fisheries. Some of other applications of GIS in reservoir fisheries are classifying and mapping of suitable habitats and potential fishing grounds; monitoring water quality, pollution, fish movement, water level fluctuations; mapping fish distribution and water parameters; and change detection and monitoring in shorelines. GIS assists fisheries managers and decision-makers to elucidate the issues and makes solutions possible by considering numerous spatial components. There is an unlimited potential to use GIS in applications for fisheries management in reservoirs. GIS makes significant contributions to ensure the sustainability of fish stocks and sustainable use of water resources in reservoirs. GIS has great potential for modelling fish distribution, abundance, habitat, estimating future capacity, and evaluation of the useful life of reservoirs. This potential could be improved by increasing the opportunities of education, experience and access on available GIS technology and data among fisheries scientists.

Keywords: Fisheries; Geographic Information System; GIS and Reservoir 


\section{International Journal of Oceanography \& Aquaculture}

\section{Introduction}

Geographic Information Systems (GIS), a computer system that integrates data, personnel, software, hardware, is planned to capably obtain, store, manage, analyse, demonstrate and report spatially referenced information [1,2]. GIS is shortly described as a computer based system for capturing, storing, checking, integrating, manipulating, analysing and displaying spatial data on the Earth [3]. Currently, GIS is the primary tool to analyse and present geo referenced data. Some advantages of GIS have been defined by Meaden and Do Chi [4]. Shortly, GIS allows to present spatial data in an easily understandable way. Also, it allows for the integration of large datasets and enabling technologies such as remote sensing. It organizes spatial information in a regular format and makes easy to produce and manage maps that have been created in digital format. Thus, updating, changing, and merging of the produced maps could be reproduced in a simple way. Maps have been produced by people for thousands of years to analyse and demonstrate information [3]. Therefore, GIS offers an advantage to reproduce maps by updating existing maps. On the other hand, GIS is not automatic decision making system however it is a tool for querying, analysing and producing maps to support the decision making processes.

Reservoirs are primarily used for water storage, irrigation, generation of hydropower, and fish production [5]. Reservoirs present high spatial heterogeneity since including characteristics of both riverine and lake environments [6]. Reservoirs show different vertical and horizontal characteristics in terms of physical habitat, primary productivity, and fish distribution [6-9]. These variations might have impacts on the movement and distribution of fish species. Fish distribution in reservoirs might also be related with productivity, prey/predator abundance, or physical features of water and habitat. Physical, biological and chemical characteristics of reservoirs also affect the population dynamics of fish such as growth, spawning, recruitment. In this context, GIS is an important tool for analysing these multidimensional spatial patterns and assessing the impacts on reservoir fisheries.

The application of GIS in fisheries science has commonly augmented since the late 1980s [10]. GIS applications in reservoir fisheries have been delayed beside other freshwater applications although GIS technology has been commonly used in marine environments [11]. Moreover, the application of GIS in reservoir fisheries assessment has been little attention while there has been widely research on fish habitat relations in reservoirs.

\section{Potential Application of GIS in Reservoir Fisheries}

The preliminary key studies on the application of GIS in fisheries were published by Meaden GJ, Kapetsky JM [12], Simpson JJ [13], Chimova M [14], Isaak DJ [15] and Meaden GJ [16]. Meaden and Kapetsky [12] studied the use of GIS and remote sensing in inland fisheries and aquaculture. Some preliminary analyses were performed for reservoir database using both traditional database and GIS approaches by Chimova and Nugent [14] and it was concluded that the data analysis was only possible by using the GIS technology.

Investigations of GIS application in fisheries management in reservoirs are increased by the improvement of technology. Applications of GIS in fisheries have been realized to focus on marine environment, lentic systems, and to evaluate the efficiency of GIS in analysing habitat and managing complex reservoir environments. Therewithal, there is a requirement to progress GIS applications in reservoir environments. Major progresses in data collection and visualization of three dimensional data, the cooperation between governments and agencies, knowledge of the characteristics of reservoirs, measurements of data for water quality in better ways are required for reservoir applications. It is crucial to collect spatial data in GIS application in reservoir fisheries. Determination of the depth layers and classification of habitats are vital for predicting possible fish distribution and fishing areas including suitable habitats for fish species and fishing activities. Fisheries and fish distribution in reservoirs have also been strongly affected by the fluctuations in water level. The fluctuations in water level influence the population dynamics of fish such as spawning and recruitment [17]. Moreover, fisheries activities are depending on the interactions between physico-chemical parameters and quality of water. Therefore, spatial analysis techniques for GIS applications in reservoir fisheries should be applied to understand spatial relationships of fish species, and the relationships between water quality, physico-chemical parameters and spatial distribution of fish populations should also be modelled by using GIS techniques. However, modelling of these relationships might be difficult due to the dynamic natures of aquatic ecosystems. To overcome this case, other progressing technologies such as remote sensing are needed to be integrated with GIS. Thus, it is more 


\section{International Journal of Oceanography \& Aquaculture}

possible that predicting primary productivity by gathering chlorophyll concentration from remotely sensed satellite imageries, estimating nutrient contents and other characteristics of aquatic environments by integrating geospatial technologies.

The productivity of a reservoir is affected by biotic (food-web, population) and a biotic factor (spatial location, climate, and hydrology). Manipulations in these factors can alter the natural carrying capacity and the fishery productivity from a reservoir. GIS was used to demonstrate relationship between fishery yield and environmental parameters by integrating fishing intensity, amount of landing, yield data of fisheries, limnological data (conductivity, chlorophyll) for nine tropical reservoirs in Sri Lanka by De Silva, et al. [18]. Ozen and Noble [19] reported that a biotic factors such as temperature, wind action, hydrological conditions could also be responsible for variation in the recruitment. Authors also pointed out that high water levels increased the recruitment. Some of other applications of GIS in reservoir fisheries are classifying and mapping of suitable habitats and potential fishing grounds; monitoring water quality, pollution, fish movement and migration, water level fluctuations; mapping fish distribution and water parameters and change detection and monitoring in shorelines [20-29].

Fisheries management has various spatial mechanisms such as migration and movement of fish populations, classification of habitat and fishing areas in addition to several serious subjects like environmental degradation and habitat loss have spatial dimensions. Consequently, decision makers, scientists and managers of fisheries and aquatic resources are required to deal with the issue of complexity. Within this context, GIS assists to elucidate the issues and makes solutions possible by considering numerous spatial components. So, GIS has great potential for fisheries management in reservoirs. Moreover, GIS is an increasingly used tool in fisheries researches and fisheries management applications for visualizing marine spatial data [30] and marine biodiversity [31], mainly in reservoir environments [11].

Successful and effective management of reservoir fisheries is essential for protecting the natural ecosystem and ensuring the sustainability of fish stock. GIS supports and offers information to resource managers, decisionmakers and fisheries managers. Therefore, it allows for combining and analysing multiple layers of geospatial data containing measurements from the environment.

\section{Future of GIS Applications in Reservoir Fisheries}

For future studies, the human impacts on the dynamics of reservoir and fish population should be assessed by using GIS for the management of reservoir fisheries. In addition, the interspecific or intraspecific interactions such as prey/predator competition should be analysed besides relationships between the environment and fish species. Also, estimating population size, relative abundance, presence or absence of fish species, and determining suitable habitats for fish populations are imperative applications for better understanding of the interactions in the dynamics of reservoirs. Consequently, there is a continuous need for the utilization of GIS to identify the location of preferred habitats, to identification of essential fish habitats, to estimate the effects of terrestrial land uses on aquatic fish habitat and water quality, to calculate area of different habitats at different water levels, to evaluate biodiversity, to determine sport/commercial fishing zones with respect to aquatic fauna and flora, and to monitor animal movements.

In conclusion, there is an unlimited potential to use GIS in applications for reservoir fisheries management. GIS makes significant contributions to ensure the sustainability of fish stocks and sustainable use of water resources in reservoirs. GIS has great potential for modelling fish distribution, abundance, habitat, estimating future capacity, and evaluation of the functional life of reservoirs. This potential could be improved by increasing the opportunities of education, experience and access on available GIS technology and data among fisheries scientists.

\section{References}

1. Burrough PA (1986) Principles of Geographic Information Systems. 1st (Edn.), Oxford University Press, New York, pp: 336.

2. Kapetsky JM, Travaglia C (1995) Geographical Information Systems and Remote Sensing: an Overview of Their Present and Potential Applications in Aquaculture. In: Nambiar KPP, Singh T (Eds.), Aqua Tech 94, Aquaculture towards the $21^{\text {st }}$ Century, INFOFISH, Kuala Lumpur, pp: 187-208.

3. De Graaf G, Marttin FJB, Aguilar-Manjarrez J, Jenness J (2003) Geographic Information Systems in Fisheries Management and Planning. FAO Fisheries Technical Paper 449, Rome, Italy, pp: 162. 


\section{International Journal of Oceanography \& Aquaculture}

4. Meaden GJ, Do Chi T (1996) Geographical Information Systems: Applications to Marine Fisheries. FAO Fisheries Technical Paper 356, Rome, Italy, pp: 335.

5. Ingole NA, Ram RN, Ranjan R, Shankhwar AK (2015) Advance Application of Geospatial Technology for Fisheries Perspective in Tarai Region of Himalayan State of Uttarakhand. Sustain Water Resour Manag 1(2): 181-187.

6. Noble RL, Jackson JR, Irwin ER, Philips JM, Churchill TN (1994) Reservoirs as Landscapes: Implications for Fish Stocking Programs. Transactions of the North American Wildlife and Natural Resources Conference 59: 281-288.

7. Buynak GL, Kornman LE, Surmont A, Mitchell B (1989) Longitudinal Differences in Electrofishing Catch Rates and Angler Catches of Black Bass in Cave Run Lake, Kentucky. N Am J Fish Manag 9: 226-230.

8. Thornton KW, Kimmel BL, Payne FE (1990) Reservoir Limnology: Ecological Perspectives. Lmnol Oceanogr 246.

9. Long JM (2000) Population Dynamics and Interactions of Three Black Bass Species in an Oklahoma Reservoir as Influenced by Environmental Variability and a Differential Harvest Regulation. PhD Thesis, Oklahoma State University, Stillwater, Oklahoma, USA.

10. Eder BL, Neely BC (2013) Use of Geographic Information Systems by Fisheries Management Agencies. Fisheries 38: 491-496.

11. Paukert CP, Long JM (2004) Geographic Information Systems Applications in Reservoirs. In: Fisher WL, Rahel FA (Eds.), Geographic Information Systems in Fisheries. American Fisheries Society, Bethesda, Maryland, USA, Pp: 85-111.

12. Meaden GJ, Kapetsky JM (1991) Geographic Information System and Remote Sensing in Inland Fisheries and Aquaculture. FAO Fisheries Technical Paper 318, FAO, Rome, Italy, pp: 262.

13. Simpson JJ (1992) Remote Sensing and Geographic Information Systems: Their Past, Present and Future Use in Global Marine Fisheries. Fish Ocean 1: 238280.

14. Chimova M, Nugent C (1993) A Fisheries GIS for Zimbabwe: an Initial Analysis of the Numbers,
Distribution and Size of Zimbabwe's Dams. Agritex Fisheries Unit-Technical Report.

15. Isaak DJ, Hubert WA (1997) Integrating New Technologies into Fisheries Science: The Application of Geographic Information System. Fisheries 22: 6-10.

16. Meaden GJ (2000) GIS in Fisheries Management. Geocoast 1: 82-101.

17. Sammons SM, Bettoli PW (2000) Population Dynamics of a Reservoir Sport Fish Community in Response to Hydrology. North Am J Fish Manage 20: 791-800.

18. De Silva SS, Amarasinghe US, Nissanka C, Wijesooriya WADD, Fernando MJJ (2001) Use of Geographical Information Systemsas a Tool for Predicting Fish Yield in Tropical Reservoirs: Case Studyon Sri Lankan Reservoirs. Fish Manag Ecol 8: 47-60.

19. Ozen O, Noble RL (2002) Relationship between Largemouth Bass Recruitment and Water Level Dynamics in a Puerto Rico Reservoir. Lake and Reserv Manage 21: 89-95.

20. Kale S (2014) Modeling of Juvenile Fish Species belong to Sparidae Family Distribution in the Shallow Waters of Gökçeada (Imbros) with GIS. MSc Thesis, Çanakkale Onsekiz Mart University, Turkey, pp: 121.

21. Kale S, Altın A, Ayyıldız H, Özen Ö (2014a) Modeling the Spatial Distribution of Juvenile Striped Sea Bream (Lithognathusmormyrus Linnaeus, 1758) in Relation to Habitat Structure in the Shallow Waters of Gökçeada Using GIS. International Symposium on Fisheries and Aquatic Sciences: FABA 2014, Trabzon, Turkey, pp: 126.

22. Kale S, Altın A, Ayyıldız H, Özen Ö (2014b) Modeling the Habitat Structure in the Shallow Waters of Gökçeada Using GIS. International Symposium on Fisheries and Aquatic Sciences: FABA 2014, Trabzon, Turkey, pp: 391.

23. Kale S, Altın A, Ayyıldız H, Özen Ö (2014c) Modeling the Spatial Distribution of Juvenile Annular Sea Bream (Diplodusannularis Linnaeus, 1758) in Relation to Habitat Structure in the Shallow Waters of Gökçeada Using GIS. International Symposium on Fisheries and Aquatic Sciences: FABA 2014, Trabzon, Turkey, pp: 392. 


\section{International Journal of Oceanography \& Aquaculture}

24. Kale S, Altın A, Ayyıldız H, Özen Ö (2015a) Spatial Distribution Modelling of Juvenile Common Pandora (Pagelluserythrinus Linnaeus, 1758) in Relation to Habitat in the Shallow Waters of Gökçeada Using GIS. $7^{\text {th }}$ International Conference on Information and Communication Technologies in Agriculture, Food and Environment: HAICTA 2015, Kavala, Greece, Pp: 672-680.

25. Kale S, Altın A, Ayyıldız H, Özen Ö (2015b) Spatial Distribution and GIS Modelling of Juvenile Garfish (Belone belone, Linnaeus, 1761) with Regard to Habitat in the Shallow Waters of Gökçeada Island (Northern Aegean Sea, Turkey. Turkish-Japanese Marine Forum-III International Workshop on Recent Developments in Marine \& Environmental Sciences, Sustainable Utilization of Water Resources, Çanakkale, Turkey, pp: 17.

26. Kale S, Acarlı D (2017a) Shoreline Change Monitoring in Atikhisar Dam Lake using Remote Sensing and Geographic Information System (GIS). VIII International Symposium on Ecology and Environmental Problems: ISEEP-2017, Çanakkale, Turkey, pp: 30.

27. Kale S, Acarlı D (2017b) Integration of Remote Sensing and Geographic Information System (GIS)
Techniques for Monitoring Shoreline Changes. VIII. International Symposium on Ecology and Environmental Problems: ISEEP-2017, Çanakkale, Turkey, pp: 202.

28. Kale S, Acarlı D (2017c) Monitoring and Calculating the Surface Area of Atikhisar Dam Lake (Çanakkale, Turkey) using Satellite Images and Geographic Information System (GIS). International Symposium on GIS Applications in Geography \& Geosciences, Çanakkale, Turkey, pp: 290.

29. Kale S, Acarlı D (2017d) Integrating Geographic Information System (GIS) and Remote Sensing for Monitoring Water Surface Area. International Symposium on GIS Applications in Geography \& Geosciences, Çanakkale, Turkey, Pp: 316.

30. Kale S, Özen Ö (2014a) Visualization of Marine Spatial Data Using GIS. $5^{\text {th }}$ International Symposium on Sustainable Development, Sarajevo, Bosnia and Herzegovina, Pp: 133.

31. Kale S, Özen Ö (2014b) GIS: An Important Tool for Visualizing Marine Biodiversity. $5^{\text {th }}$ International Symposium on Sustainable Development, Sarajevo, Bosnia and Herzegovina, Pp: 55.

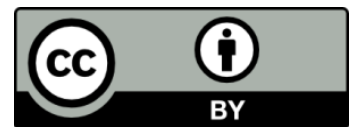

